\title{
Analysis of Climate of Southwestern Nigeria for Building Design
}

\author{
Lawal, Akinloye ${ }^{1}$, Akinpade Joseph ${ }^{2}$ and Adebisi Makinde ${ }^{2}$ \\ ${ }^{I}$ Department of Project Management Technology, Federal University of Technology, \\ Akure. Ondo State. Nigeria \\ ${ }^{2}$ Department of Building Technology, The Polytechnic, Ibadan. Oyo State. Nigeria \\ ${ }^{2}$ Department of Building Technology, Osun State College of Technology, \\ Esa Oke, Osun State. Nigeria
}

*Corresponding Author: Lawal, Akinloye, Department of Project Management Technology, Federal University of Technology, Akure. Ondo State. Nigeria.

\begin{abstract}
Southwestern Nigeria lies within what has been classified as warm humid climate. This implies that design in terms of orientation of windows, quantity of sun radiation excluded from the indoor, choice of building materials for walls, windows, and roofs can be the same with or without little variation anywhere within the Southwestern Nigeria. There are variations of climate in various localities of the zone. Some of this variation may necessitate different design solutions. In this study, the climate data for six towns were obtained from Nigeria Metrological Agency. The data were quantitatively analysed using graphical and application of Mahoney method. Building design decisions for each of the towns was suggested based on the analysis.
\end{abstract}

Keywords: Contemporary, Bioclimatic, Climate, Passive.

\section{INTRODUCTION}

Southwestern Nigeria has two distinct seasons; the dry season, from November to March and the raining season, which is from April to October. Nigeria as a country in the south of Sahara has her climate controlled by heating and cooling of the land mass as well as that of the body of water in the Atlantic Ocean. Ogunsote (2001) identified the six zones of Nigeria with costal and forest zones for Southwestern Nigeria. Ojo (2007) ascertained that migration and pulsation of the air masses are the fundamental basis of Nigeria climate.

Costa (2014) and Ajibola (2015) established that most traditional and contemporary buildings in Nigeria are not bioclimatic. This called for more studies on various zones of the country to fully establish this assertion. Most traditional buildings in Nigeria have laid too much emphasis on sociocultural and economic factors (Costa, 2014) while contemporary buildings have depended on imported building materials without consideration for micro and macro climatic situation. They have shapes and forms that are not responding to passive energy, not properly oriented and appropriate fabrics are not specified to prevent or minimize solar heat gain into the buildings. Occupants of these indoor spaces cannot enjoy adequate thermal comfort because of lack of cross ventilation (Akinbami, 2012 and Lawal, 2008).

Henderson (2010) in Ajibola (2015) ascertained that climatic elements, which have great impact on our daily life, are temperature, precipitation, wind speed and direction, topography, radiation, relative humidity and air pressure. Temperature, relative humidity and air movement affect building design decisions with respect to human physiological comfort. To produce climate responsive or environmentally conducive buildings in Southwestern Nigeria, it is necessary to carefully examine and analyse climate data nearest to the building location. To achieve design and construction with adequate natural thermal comfort in this part of the world demands that such buildings should have forms and shapes which should be responsive to climatic parameters. Parameters like temperature, relative humidity wind speed, wind direction, rainfall, and radiation should be considered in building design (Doxiadis, 2006). 


\section{STUDY AREA}

Southwestern Nigeria lies within longitude $2^{0} 48^{\prime}-6^{0} 0^{\prime} \mathrm{E}$ and latitude $5^{0} 5^{\prime}-9^{0} 12^{\prime} \mathrm{N}$. Southwestern Nigeria is located in the south western part of Nigeria and shares land borders with the Republic of Benin in the west, Kogi and Edo States in the east, and Kwara State in the north. Its coast in the south lies on the Gulf of Guinea on the Atlantic Ocean. The largest and most influential ethnic group in Southwestern Nigeria is Yoruba. In terms of religion Southwestern Nigeria is roughly split half and half between Muslims and Christians with a very small minority who practice traditional religion. Southwestern Nigeria is divided into six states namely Oyo, Ogun, Osun, Ekiti, Ondo and Lagos state. Southwestern Nigeria's largest city is Lagos. Lagos has grown from 300,000 in 1950 to an estimated 15 million today, and the Nigerian government estimates that city will have expanded to 25 million residents by 2025 .

\section{MeTHOdOLOGY}

Climate and passive energy parameters interact to provide endo-climate within which man experiences a thermal environment peculiar to the occupied spaces. Climate parameters include air temperature, rainfall, relative humidity and radiation. The data collected from Metrological Agency included monthly maximum and minimum relative humidity, monthly maximum and minimum air temperature, rainfall and sun radiation. Climatic information obtained from each of the six towns with each representing each of the States in Southwestern Nigeria was quantitatively analyzed.

Analyses carried out were of two types. The climatic parameters for each of the six towns were graphically presented. This is to determine the effect of each of the elements and to examine the variability of each of the climatic element from one town to the other. Figures $1-6$ show the graphically climatic analysis of the six towns in Southwestern Nigeria. Table 1 shows the summary of recommendation from Mahoney Tables on state basis and table 2 shows a typical Mahoney analytical sheet. Figure 1A shows the graphical representation of design solution for each of the cities representing each of the states.

\section{Data Analysis AND Discussion of Results}

The study determines the variability of climate within Southwestern Nigeria in order to propose appropriate building design solutions in the six selected towns. Szokolay (1982) stated that existing climate classifications are too general and therefore not useful for building design purpose. The graphical presentation of the climate elements shows that there is slight variation in the climatic condition within the Southwestern Nigeria.

Figure 1A shows the design solution for each of the states. Figures $1-6$ show the histogram of relative humidity, rainfall, temperature and radiation for each of the towns while these suggest that design solutions with respect to thermal comfort should one town be different from to another. The need then arises for a precise climatic analysis to be able to determine to what extent design solutions should be varied. Komolafe and Agarwal (2007) and Ogunsote (2001) in Ajibola (2015) had described Mahoney method of climate analysis as a method of determining the human comfort, requirements and satisfactory design principles. However, Ajibola's method was adopted in this study.

Table 1 shows the summary of recommendation from Mahoney Tables on states basis. It allows appropriate preliminary design solutions about the following parameters, layout of building, spacing of building, air movement within building spaces, size of openings, types of walls, roofs, floor materials in terms of heat capacity, need for the provision of outdoor space and need for the provision of indoor space and rain protection. All the six towns were analysed based on these parameters. Table 2 shows a typical Mahoney analytical sheet while table 3 shows the application of Mahoney analysis to Southwestern Nigeria. The required design parameters necessary for preliminary design decisions for buildings in Southwestern Nigeria based on Mahoney analysis are listed in column 1 of table 2; column 2 shows the climate indicators used to arrive at the design solution. The design indicators are the aridity and humidity levels in each of the six towns. Column 3 shows all the available design options while column 4 shows the number of towns that have each design solution. Design solutions details of indicators, elevation of each of the towns and elevation range within each state are presented in table 3. The appropriate design solutions relevant to each state are shown on the map of Southwestern Nigeria in Figure 7. Most part of Southwestern Nigeria experience variation in humidity 
Analysis of Climate of Southwestern Nigeria for Building Design

and aridity. High percentage of humidity and low percentage of aridity is observed in the lower attitudes of Southwestern Nigeria as informed in Ajibola (2015).

Table1. Summary of Recommendation from Mahoney Tables on States Basis

\begin{tabular}{|c|c|c|c|c|c|c|}
\hline RECOMMENDATION & $\begin{array}{l}\text { Lagos } \\
\text { State }\end{array}$ & $\begin{array}{l}\text { Oyo } \\
\text { State }\end{array}$ & $\begin{array}{l}\text { Ogun } \\
\text { State }\end{array}$ & $\begin{array}{l}\text { Osun } \\
\text { State }\end{array}$ & $\begin{array}{l}\text { Ondo } \\
\text { State }\end{array}$ & $\begin{array}{l}\text { Ekiti } \\
\text { State }\end{array}$ \\
\hline \multicolumn{7}{|l|}{ LAYOUT } \\
\hline $\begin{array}{l}\text { 1Building orientation on } \\
\text { east-west axis to reduce } \\
\text { exposure to sun }\end{array}$ & $\bullet$ & $\bullet$ & $\bullet$ & $\bullet$ & • & $\bullet$ \\
\hline \multicolumn{7}{|l|}{$\begin{array}{l}2 \text { Compact courtyard } \\
\text { planning }\end{array}$} \\
\hline \multicolumn{7}{|l|}{ SPACING } \\
\hline $\begin{array}{l}3 \text { Open spacing for breeze } \\
\text { penetration }\end{array}$ & $\bullet$ & & & & & \\
\hline $\begin{array}{l}\text { 4. As } 3 \text { but protection from } \\
\text { cold /hot wind }\end{array}$ & & $\bullet$ & $\bullet$ & $\bullet$ & $\bullet$ & $\bullet$ \\
\hline \multicolumn{7}{|l|}{ 5. Compact planning } \\
\hline \multicolumn{7}{|l|}{ AIR MOVEMENT } \\
\hline $\begin{array}{l}\text { 6. Rooms single banked. } \\
\text { Permanent provision for air } \\
\text { movement }\end{array}$ & $\bullet$ & $\bullet$ & $\bullet$ & $\bullet$ & $\bullet$ & $\bullet$ \\
\hline \multicolumn{7}{|l|}{$\begin{array}{l}\text { 7. Double banked rooms } \\
\text { with temporary Provision } \\
\text { for air movement }\end{array}$} \\
\hline \multicolumn{7}{|l|}{$\begin{array}{l}\text { 8. No air movement } \\
\text { requirement }\end{array}$} \\
\hline \multicolumn{7}{|l|}{ OPENINGS } \\
\hline $\begin{array}{l}\text { 9. Large openings. } 40 \%- \\
80 \% \text { of } \mathrm{N} \text { and } \mathrm{S} \text { walls }\end{array}$ & $\bullet$ & $\bullet$ & $\bullet$ & $\bullet$ & $\bullet$ & $\bullet$ \\
\hline \multicolumn{7}{|l|}{$\begin{array}{l}\text { 10. Very small openings. } \\
10 \%-20 \%\end{array}$} \\
\hline \multicolumn{7}{|l|}{$\begin{array}{l}\text { 11. Medium openings. } \\
20 \%-40 \%\end{array}$} \\
\hline \multicolumn{7}{|l|}{ WALLS } \\
\hline $\begin{array}{l}\text { 12. Light walls, short time } \\
\text { lag. }\end{array}$ & $\bullet$ & & $\bullet$ & & & \\
\hline $\begin{array}{l}\text { 13. Heavy external and } \\
\text { internal walls. }\end{array}$ & & $\bullet$ & & $\bullet$ & $\bullet$ & $\bullet$ \\
\hline \multicolumn{7}{|l|}{ ROOFS } \\
\hline 14. Light insulated roofs. & $\bullet$ & $\bullet$ & - & $\bullet$ & & $\bullet$ \\
\hline \multicolumn{7}{|l|}{$\begin{array}{l}\text { 15. Heavy roofs, over } 8 \\
\text { hours time lag. }\end{array}$} \\
\hline \multicolumn{7}{|l|}{ OUTDOOR SLEEPING } \\
\hline \multicolumn{7}{|l|}{ 16. Space for outdoor } \\
\hline \multicolumn{7}{|l|}{ sleeping required. } \\
\hline \multicolumn{7}{|l|}{ RAIN PROTECTION } \\
\hline $\begin{array}{l}17 \text { Protection from heavy } \\
\text { rain needed }\end{array}$ & $\bullet$ & & & & & \\
\hline
\end{tabular}

Source: Authors Analysis of Field Work (2005)

Table2. Typical Mahoney Analytical Sheet

\begin{tabular}{|l|l|l|l|l|}
\hline $\begin{array}{l}\text { Design } \\
\text { Parameters }\end{array}$ & Indicators For Design & Design & Design Operation & $\begin{array}{l}\text { No. } \\
\text { Locations } \\
\text { (States) }\end{array}$ \\
\hline Layout & $\mathrm{A} 1(0-10)$ or A1 $(11-12)+\mathrm{A} 3(5-12)$ & $1^{1}$ & $1^{2}$ & $\begin{array}{l}\text { Building orientation on } \\
\text { east-west axis to reduce } \\
\text { exposure to sun } \\
\text { Compact } \\
\text { planning courtyard }\end{array}$ \\
\hline
\end{tabular}


Analysis of Climate of Southwestern Nigeria for Building Design

\begin{tabular}{|c|c|c|c|c|}
\hline Spacing & $\begin{array}{l}\mathrm{H} 1(11-12) \\
\mathrm{H} 1(2-10) \\
\mathrm{H} 1(0-1)\end{array}$ & $\begin{array}{l}2^{1} \\
2^{2}\end{array}$ & $\begin{array}{l}\text { Open spacing for breeze } \\
\text { penetration } \\
\text { Open spacing for breeze } \\
\text { penetration but protection } \\
\text { from wind } \\
\text { Compact planning }\end{array}$ & $\begin{array}{l}1 \\
5 \\
0\end{array}$ \\
\hline Air Movement & $\begin{array}{l}\mathrm{H} 1(3-12) \text { or } \mathrm{H} 1(1-2)+\mathrm{A} 1(0-5) \\
\mathrm{H} 1(1-2)+\mathrm{A} 1(6-12) \text { or } \mathrm{H} 1(0)+\mathrm{H} 2(2-12) \\
\mathrm{H} 1(0)+\mathrm{H} 2(0-1)\end{array}$ & $3^{2}$ & $\begin{array}{l}\text { Rooms single banked with } \\
\text { permanent provision for } \\
\text { air movement } \\
\text { Rooms single banked with } \\
\text { temporary provision for } \\
\text { air movement } \\
\text { No air movement required }\end{array}$ & $\begin{array}{l}6 \\
0 \\
0\end{array}$ \\
\hline $\begin{array}{ll}\text { Size } & \text { of } \\
\text { Openings } & \end{array}$ & $\begin{array}{l}\mathrm{A} 1(0-1)+\mathrm{A} 3(0) \\
\mathrm{A} 1(11-12)+\mathrm{A} 3(0-1)\end{array}$ & $\begin{array}{l}4^{1} \\
4^{2}\end{array}$ & $\begin{array}{l}\text { Large openings, } 40 \%- \\
80 \% \text { of } \mathrm{N} \text { and } \mathrm{S} \text { walls } \\
\text { Very small openings. } \\
10 \%-20 \%\end{array}$ & $\begin{array}{l}6 \\
0\end{array}$ \\
\hline Walls & $\begin{array}{l}\mathrm{A} 1(0-2) \\
\mathrm{A} 1(3-12)\end{array}$ & $\begin{array}{l}5^{1} \\
5^{2}\end{array}$ & $\begin{array}{l}\text { Light walls, short time lag } \\
\text { Heavy external and } \\
\text { internal walls }\end{array}$ & $\begin{array}{l}2 \\
4\end{array}$ \\
\hline Roofs & $\begin{array}{l}\mathrm{A} 1(0-5) \\
\mathrm{A} 1(6-12)\end{array}$ & $\begin{array}{l}6^{1} \\
6^{2}\end{array}$ & $\begin{array}{l}\text { Light insulated roofs } \\
\text { Heavy roofs, over } 8 \text { hour's } \\
\text { time lag }\end{array}$ & $\begin{array}{l}5 \\
0\end{array}$ \\
\hline $\begin{array}{l}\text { Outdoor } \\
\text { Sleeping }\end{array}$ & $\mathrm{A} 2(2-12)$ & $7^{1}$ & $\begin{array}{l}\text { Space for outdoor sleeping } \\
\text { required }\end{array}$ & 0 \\
\hline $\begin{array}{l}\text { Rain } \\
\text { Protection }\end{array}$ & $\mathrm{H} 3(3-12)$ & $8^{1}$ & $\begin{array}{l}\text { Protection from heavy rain } \\
\text { needed }\end{array}$ & 1 \\
\hline
\end{tabular}

Table3. Application of Mahoney Analysis to Southwestern Nigeria

\begin{tabular}{|c|c|c|c|c|c|c|c|c|c|c|c|c|c|c|c|c|c|c|c|c|c|c|c|c|}
\hline & $1^{1}$ & $\mathbf{1}^{2}$ & $2^{1}$ & $\mathbf{2}^{2}$ & $\mathbf{2}^{3}$ & $\mathbf{3}^{1}$ & $\mathbf{3}^{2}$ & $\mathbf{3}^{3}$ & $4^{1}$ & $4^{2}$ & $5^{1}$ & $5^{2}$ & $6^{1}$ & $6^{2}$ & $7^{1}$ & $8^{1}$ & H1 & H2 & H3 & A1 & A2 & A3 & EL & $\begin{array}{c}\text { EL } \\
\text { Range }\end{array}$ \\
\hline 1 & 0 & & 0 & & & 0 & & & 0 & & 0 & & 0 & & & 0 & 8 & 1 & 1 & 3 & 0 & 0 & $\begin{array}{l}0- \\
50\end{array}$ & $\begin{array}{l}0- \\
500\end{array}$ \\
\hline 2 & 0 & & & 0 & & 0 & & & 0 & & & 0 & 0 & & & & 9 & 0 & 2 & 3 & 0 & 0 & \begin{tabular}{|l|}
$50-$ \\
200
\end{tabular} & $\begin{array}{l}50- \\
500\end{array}$ \\
\hline 3 & 0 & & & 0 & & 0 & & & 0 & & 0 & & 0 & & & & 7 & 1 & 2 & 4 & 0 & 0 & \begin{tabular}{|l|}
$50-$ \\
200
\end{tabular} & $\begin{array}{c}50- \\
1000\end{array}$ \\
\hline 4 & 0 & & & 0 & & 0 & & & 0 & & & \begin{tabular}{l|l}
0 \\
\end{tabular} & 0 & & & & 9 & 0 & 1 & 3 & 0 & 0 & $\begin{array}{c}200 \\
- \\
500\end{array}$ & $\begin{array}{l}200- \\
2000\end{array}$ \\
\hline 5 & 0 & & & 0 & & 0 & & & 0 & & & 0 & & & & & 10 & 0 & 2 & 2 & 0 & 0 & $\begin{array}{c}500 \\
- \\
1000\end{array}$ & $\begin{array}{c}50- \\
1000\end{array}$ \\
\hline 6 & 0 & & & 0 & & 0 & & & 0 & & & \begin{tabular}{l|l} 
\\
\end{tabular} & 0 & & & 0 & 12 & 0 & 5 & 0 & 0 & 0 & $\begin{array}{c}200 \\
- \\
500\end{array}$ & $\begin{array}{c}200- \\
2000\end{array}$ \\
\hline
\end{tabular}

$\underline{\text { KEY }}$

$\mathbf{1}=\quad$ Lagos $($ Lagos State $)$

$\mathrm{EL}=$ Elevation Level

$\mathbf{2}=\quad$ Ibadan (Oyo State)

EL Range=Elevation Level Range

3= Abeokuta (Ogun State)

$4=$ Osogbo (Osun State)

$\mathbf{5}=\quad$ Ondo (Ondo State)

$\mathbf{6}=\quad$ Ado Ekiti (Ekiti State) 


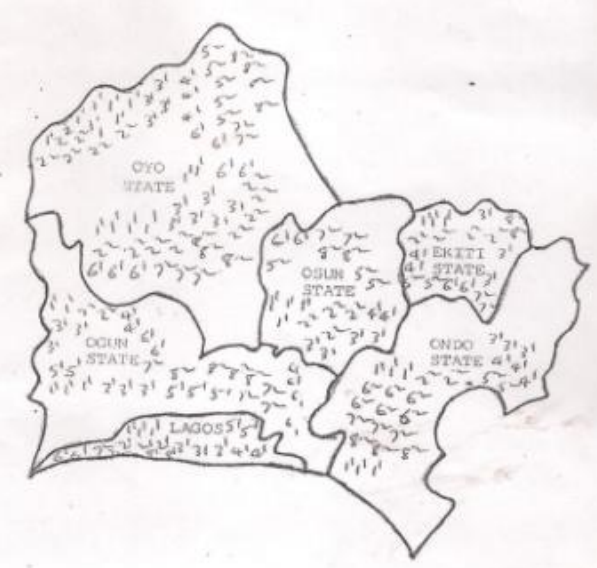

Figure1A. Design Solutions for Each of the Southwestern Nigerian States

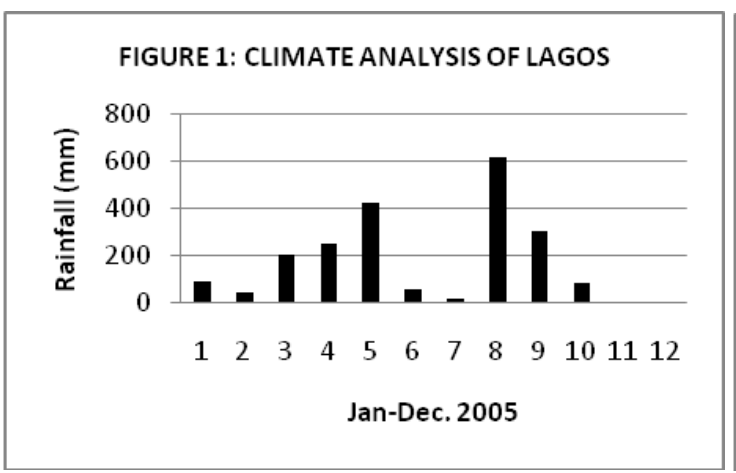

FIGURE 2: CLIMATE ANALYSIS OF IBADAN

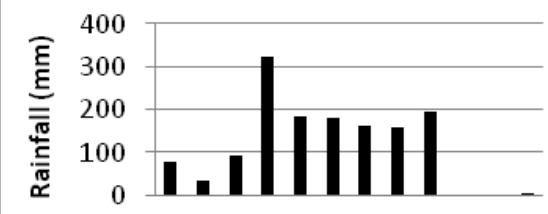

12334566789101112

Jan-Dec. 2005
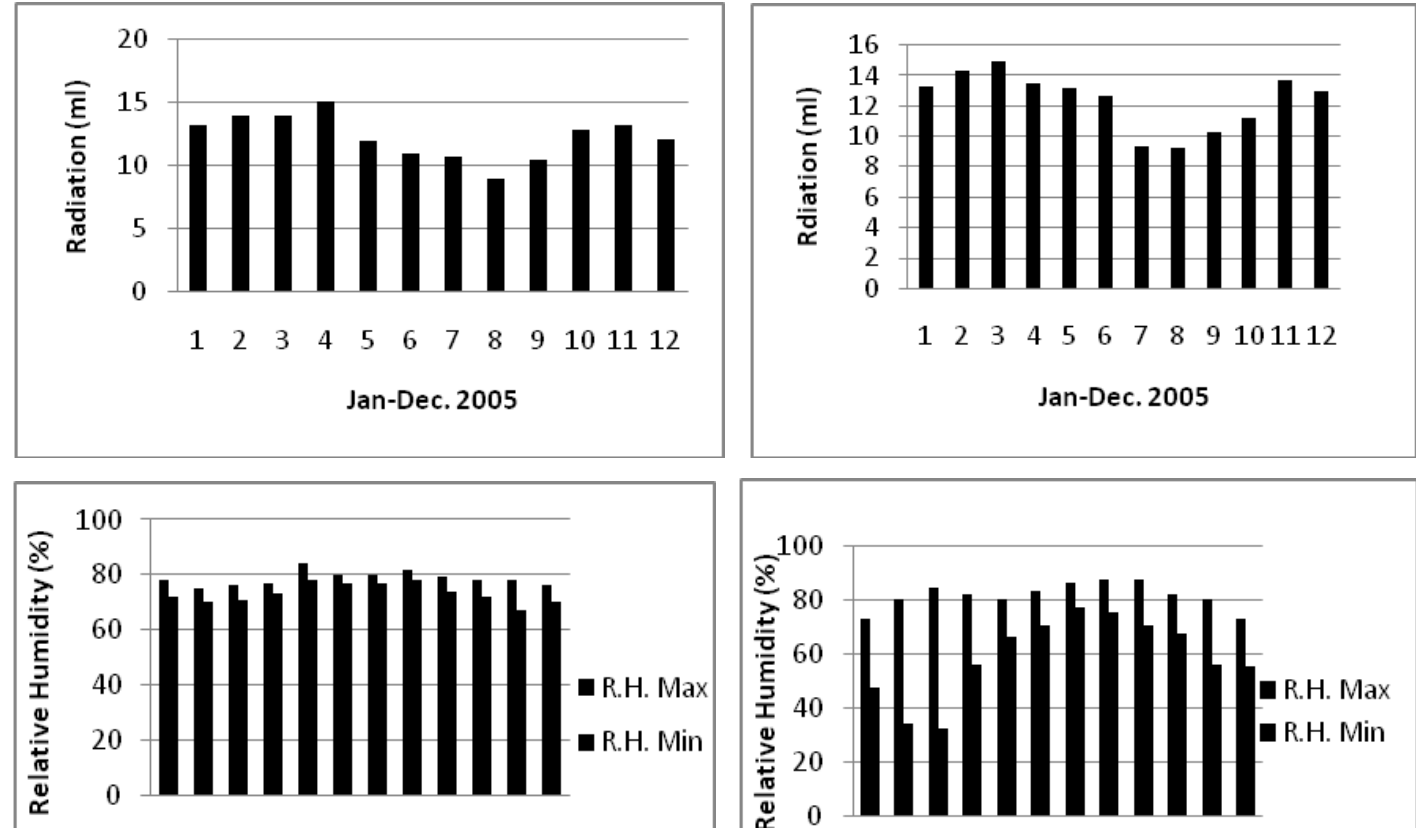

$\begin{array}{llllllllll}1 & 2 & 3 & 4 & 5 & 6 & 7 & 8 & 9 & 101112\end{array}$

Jan-Dec. 2005

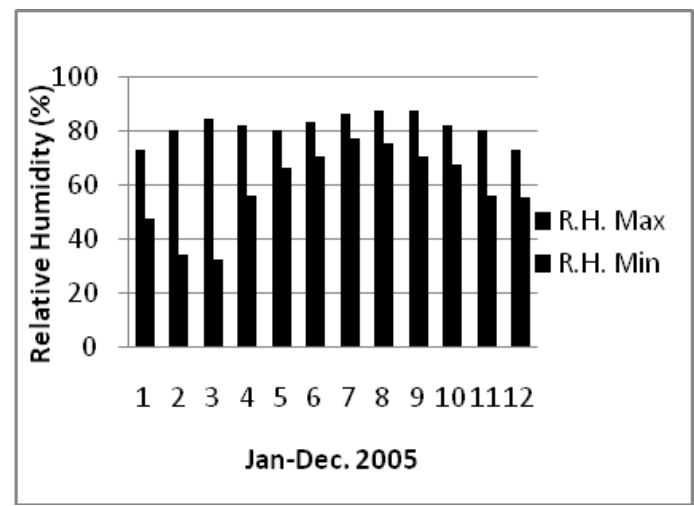



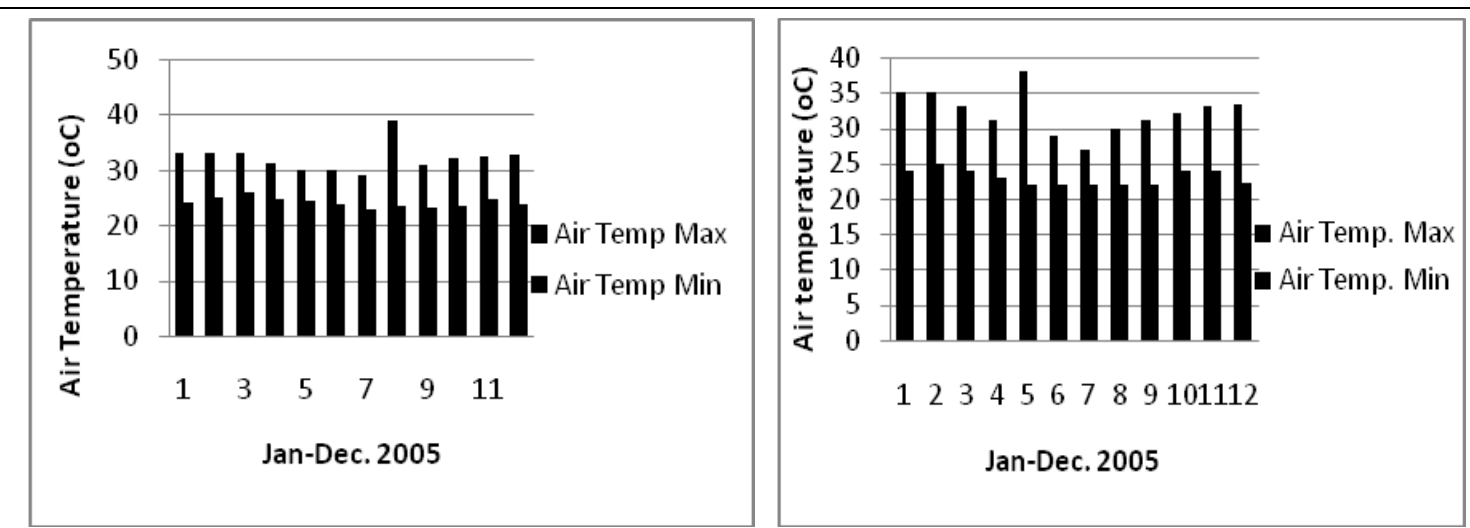

123456789101112

Jan-Dec. 2005
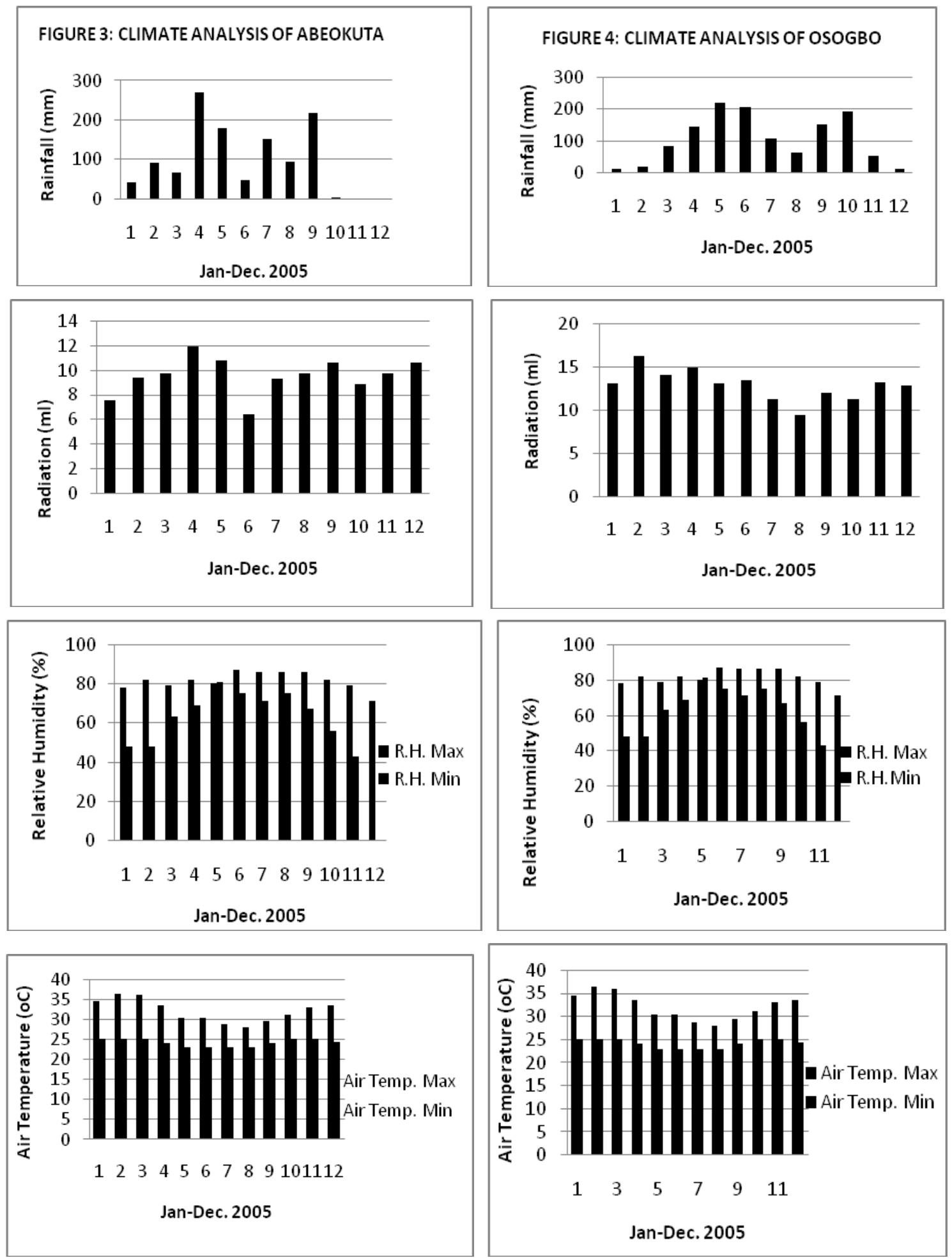

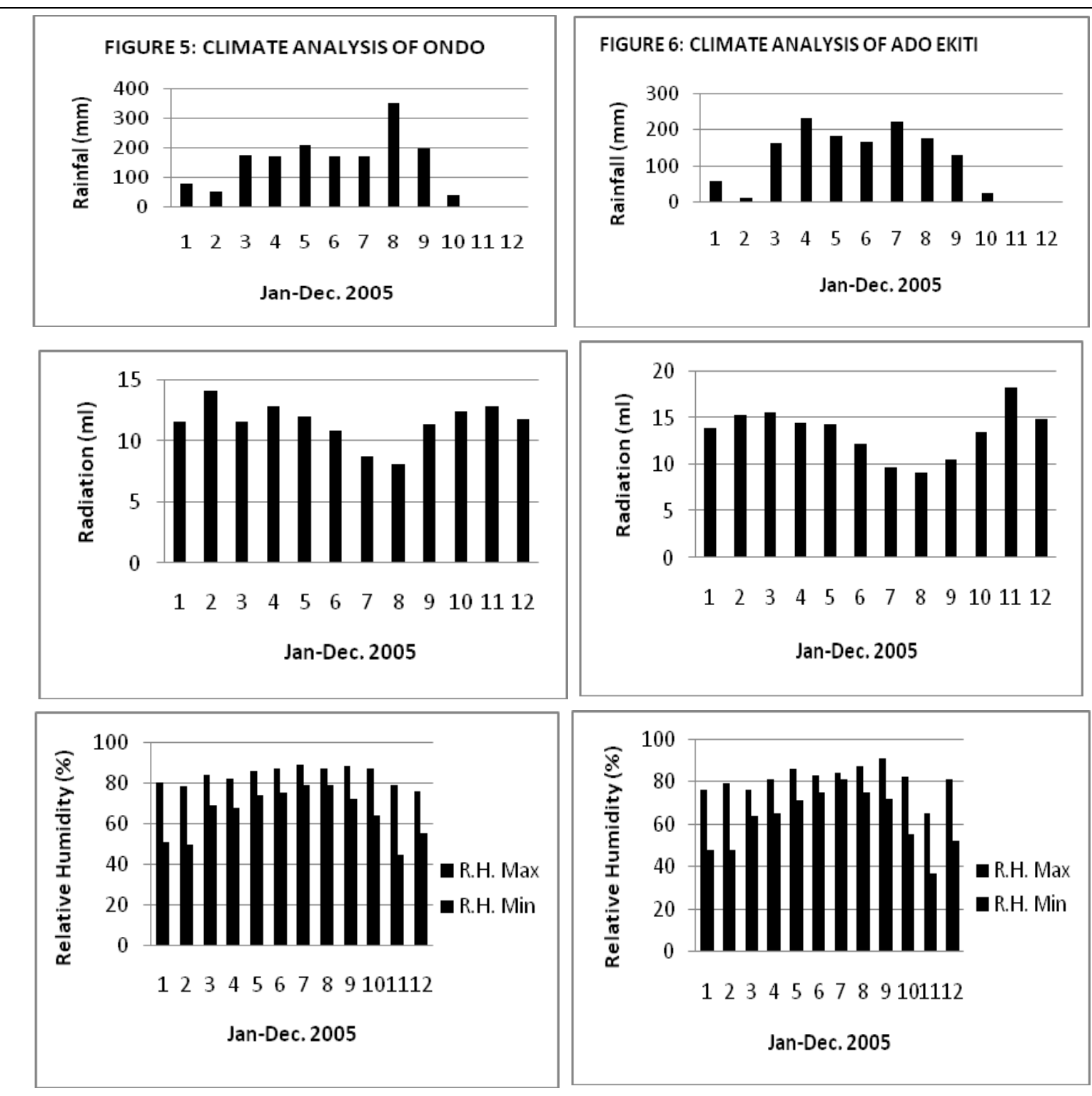

123456789101112

Jan-Dec. 2005
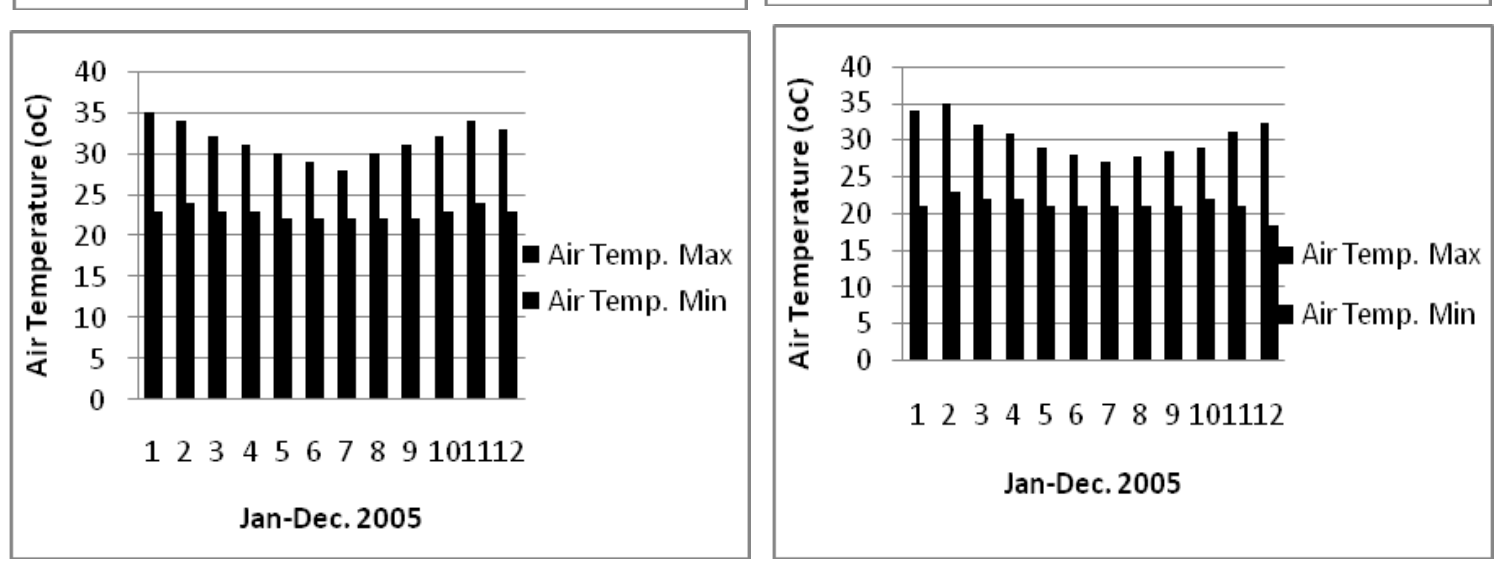

\section{CONCLUSION AND RECOMMENDATION}

Designers, architects and professionals in the built environment throughout Southwestern Nigeria and despite the significant differences in the local climate conditions, the variation in local climate condition is as a result of distance from the ocean and the desert and vegetation should not replicate building designs.

The study revealed that design solutions are the same with respect to orientation layout, air movement, size of openings and material for roofs while there is variation in the design solution in respect of spacing, materials for walls, and provision of protection for rain. It is therefore evident that Southwestern Nigeria cannot be regarded as homogenous warm humid climate. The study 
recommends that peculiarities of climatic variables in every part of the Southwestern part of the country should be considered before designs of buildings can be done.

\section{REFERENCES}

[1] Ajibola, K. (2015); Analysis of Climate of Nigeria for Building Design. Review of Growth and Change, $4,(2)$.

[2] Akinbami, J. F. K. (2012); Energy Conservation in Public Community and Industrial Buildings. Paper presented on Energy Conservation and Your Profit in Deregulation Power Regime Conference, Lagos, 4 - 6.

[3] Costa, R. (2014); Architecture in Black Africa between Developments and Tradition. SolarWind Energy. London, 6, (4), 383 - 387.

[4] Doxiadis, C. A. (2006); How Can We Learn about Man and His Settlement's in Rapport. (Ed) The Mutual Interaction of People and Their Built Environment. A Cross-cultural Perspective. The Hague, Mouton, 23 - 42.

[5] Henderson, S. (2010); "Contemporary Climatology". New York, Longman, 341 - 345.

[6] Komolafe, L. K. and Agarwal, K. N. (2007); Climatic Zones and Thermal Standards for Low Cost Houses in Nigeria. Proceedings of International Conference on Low Cost Housing for Development Countries. Rookee India 1, 505 - 516.

[7] Lawal, A, F. (2008): "Assessment of Public Building Designs for Energy Conservation in Southwestern Nigeria" Unpublished Ph. D. Thesis, Technology Planning and Development Unit, Faculty of Technology, Obafemi Awolowo University, Ile-Ife. Nigeria.

[8] Ogunsote, O. O. (2001); Introduction to Building Climatology, Zaria. Ahmadu Bello University Press, $141-153$.

[9] Ojo, O. (2007); The Climates of West Africa. London, Heinemann Educational Books Ltd. Szokolay, S. V. (1982); Climate Data and its use in Design. Proceeding of the First International Conference in Passive and Low Energy Alternatives. Sept. 13 - 15, Bermuda.

\section{AUTHOR's BIOGRAPHY}

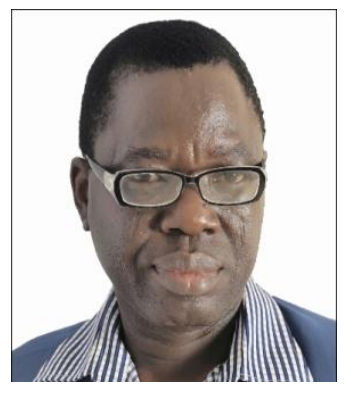

Dr. Akinloye Lawal, holds H.N.D Architecture, B. Sc. Building, M. Sc. (Technology Management) with emphasis in Project Technology Management, Ph. D. (Technology Management) with emphasis in Building Climatology and Energy Management in Buildings. He is a Fellow, Nigerian Institute of Building (FNIOB), Fellow, Institute of Development Finance and Project Management (FIDFPM), Registered Builder, Council of Registered Builders of Nigeria (CORBON) and Corporate Member, Nigeria Institute of Building (MNIOB). He is a Reviewer of many Academic and Professional Journals which includes Nigerian Institute of Building Journals, Nigerian Journal of Environmental Development and Management, Nigerian Journal of Engineering and Environmental Sciences. He is presently an Associate Professor of Construction Project Management in the Department of Project Management Technology, Federal University of Technology. Akure. Ondo State. Nigeria.

Citation: Lawal, Akinloye et al. (2017) Analysis of Climate of Southwestern Nigeria for Building Design, International Journal of Constructive Research in Civil Engineering, 3(3), pp.38-45.

Copyright: (C) 2017 : Lawal, Akinloyel. This is an open-access article distributed under the terms of the Creative Commons Attribution License, which permits unrestricted use, distribution, and reproduction in any medium, provided the original author and source are credited. 